\title{
A Phase I, open-label, dose escalation study of MGA271 in combination with pembrolizumab in patients with B7-H3-expressing melanoma, squamous cell cancer of the head and neck, or squamous cell non-small cell lung cancer
}

\author{
Jan Baughman ${ }^{1}$, Deryk Loo ${ }^{1}$, Francine Chen ${ }^{1}$, Paul Moore ${ }^{2}$, Ezio Bonvini ${ }^{2}$, James Vasselli2 ${ }^{*}$, Jon Wigginton², \\ Roger Cohen ${ }^{3}$ \\ From 30th Annual Meeting and Associated Programs of the Society for Immunotherapy of Cancer \\ (SITC 2015) \\ National Harbor, MD, USA. 4-8 November 2015
}

\section{Background}

MGA271 is an Fc optimized humanized IgG1 monoclonal antibody that binds to B7-H3 (CD276), a member of the B7 family, currently undergoing Phase I testing. The Fc domain is engineered for enhanced binding to the activating $\mathrm{F} c \gamma \mathrm{R}, \mathrm{CD} 16 \mathrm{~A}$, and decreased binding to the inhibitory Fc $\gamma R$, CD32B. B7-H3 has limited expression in normal tissue and high expression in multiple tumors including melanoma (M), squamous cell cancer of the head and neck (SCCHN) and non-small cell lung cancer (NSCLC). The correlation between $\mathrm{B} 7-\mathrm{H} 3$ overexpression and poor prognosis in certain cancers suggests a role for B7-H3 in tumor escape. Despite the clinical success of agents including anti-CTLA-4, anti-PD-1 and anti-PD-L1 antibodies, the majority of patients with M, SCCHN or NSCLC progress nonetheless, and substantial unmet need exists for these patients. The underlying hypotheses for combining MGA-271 (anti-B7-H3) with pembrolizumab (antiPD-1) are: 1) combining immune-modulating agents may mediate additive or synergistic antitumor activity (e.g. anti-CTLA-4+anti-PD-1), and can do so where neither single agent has pronounced antitumor activity (e.g. antiPD-1+anti-LAG-3), 2) coordinate engagement of both innate and adaptive immunity, 3) both agents may enhance the immune response against tumors via modulation of $\mathrm{T}$ cell immunosuppression, and 4) limited

${ }^{2}$ MacroGenics, Rockville, MD, USA

Full list of author information is available at the end of the article expression of B7-H3 on normal tissues may help focus an immune attack on tumors, limiting the risk of immunerelated adverse events (irAEs) resulting from the disruption of self-tolerance, allowing MGA271 to be combined more readily with other immune-modulating agents, including anti-CTLA-4 and anti-PD-1 antibodies. /PD-1 /PD-L1.

\section{Methods}

This US, multi-center, open-label trial (NCT02475213) enrolls patients with advanced B7-H3-expressing SCCHN, $M$, or squamous NSCLC. Progression on previous checkpoint inhibitor is allowed. Following a $3+3+3$ dose escalation scheme, successive cohorts of patients will receive escalating doses of weekly IV MGA271 beginning at 3 $\mathrm{mg} / \mathrm{kg}$, and a fixed dose of IV pembrolizumab $(2 \mathrm{mg} / \mathrm{kg}$ ) administered every three weeks. Both study drugs will be administered starting on Day 1 of the study and given for up to one year. A three-cohort expansion phase will open at the established MTD with 16 patients each with M, SCCHN and NSCLC. The primary objective of this study is to determine the safety, dose-limiting toxicity and maximum tolerated dose of the MGA271/pembrolizumab combination. Secondary objectives include evaluation of pharmacokinetics, pharmacodynamics and preliminary anti-tumor activity of this combination. This novel study will provide the first clinical assessment of coordinated targeting of both the B7-H3 and PD-1/PD-L1 axes in patients with advanced cancer. 


\section{Trial registration}

ClinicalTrials.gov identifier NCT02475213.

\section{Authors' details}

${ }^{1}$ MacroGenics, San Francisco, CA, USA. ${ }^{2}$ MacroGenics, Rockville, MD, USA.

${ }^{3}$ University of Pennsylvania, Philadelphia, PA, USA.

Published: 4 November 2015

doi:10.1186/2051-1426-3-S2-P177

Cite this article as: Baughman et al:: A Phase I, open-label, dose

escalation study of MGA271 in combination with pembrolizumab in

patients with B7-H3-expressing melanoma, squamous cell cancer of the

head and neck, or squamous cell non-small cell lung cancer. Journal for

ImmunoTherapy of Cancer 2015 3(Suppl 2):P177.

Submit your next manuscript to BioMed Central and take full advantage of:

- Convenient online submission

- Thorough peer review

- No space constraints or color figure charges

- Immediate publication on acceptance

- Inclusion in PubMed, CAS, Scopus and Google Scholar

- Research which is freely available for redistribution

Submit your manuscript at www.biomedcentral.com/submit
C Biomed Central 